Asian-Australasian Journal of Food Safety and Security ISSN 2523-1073 (Print) 2523-2983 (Online) www.ebupress.com/journal/aajfss

\title{
Article \\ Socio-economic status of fish retailers in Jashore sadar, Bangladesh
}

\author{
Mita Rani Adhikary ${ }^{1}$, Md. Aminur Rahman ${ }^{2}$, Abdulla-Al-Asif ${ }^{2,3}$ and Ripon Kumar Adhikary ${ }^{2 *}$ \\ ${ }^{1}$ Department of Economics, Faculty of Social Sciences, Islamic University, Bangladesh \\ ${ }^{2}$ Department of Fisheries and Marine Bioscience, Faculty of Biological Science and Technology, Jessore \\ University of Science and Technology, Jessore, 7408, Bangladesh \\ ${ }^{3}$ Department of Aquaculture, Faculty of Fisheries, Bangladesh Agricultural University, Mymensingh, 2202, \\ Bangladesh
}

*Corresponding author: Ripon Kumar Adhikary, Department of Fisheries and Marine Bioscience, Faculty of Biological Science and Technology, Jessore University of Science and Technology, Jessore, 7408, Bangladesh. Phone: +8801911969016; E-mail: rk.adhikary@just.edu.bd

Received: 07 November 2018/Accepted: 21 November 2018/ Published: 29 November 2018

\begin{abstract}
The study was conducted to determine the fish retailer's livelihood and socio-economic status in three markets of Jashore for a period of six months from February to August, 2016. The average net profit of fish retailers was found higher in Boro bazaar (Tk.350) followed by Palbari bazaar (Tk.325), Chuadanga Bus Stand bazaar (TK.275). The average age groups of 20-65 years were found among the markets. The study shows that $53 \%$ fish retailers had nuclear family and $47 \%$ had joint family. Most of the housing conditions were kacha (69\%) and Muslim fish retailers were predominant in all markets. Among the total 45 traders interviewed, $42 \%$ were illiterate, $31 \%$ have primary level education, $24 \%$ have secondary level education and none of them had bachelor level of education. It was found that fish retailers of Boro bazaar and Palbari bazaar sold an average of $35 \mathrm{~kg}$ fish daily, compared with Chuadanga Bus Stand bazaar $15 \mathrm{~kg}$ per day. The daily supply of fish in Boro bazaar can be estimated at $1.6 \mathrm{MT}(25$ retailers' $\times 65 \mathrm{~kg})$ while $0.3 \mathrm{MT}(15$ retailers $\times 20 \mathrm{~kg})$ and $0.45 \mathrm{MT}(15$ retailers $\times 30 \mathrm{~kg}$ ) in C.B Bazar and Palbari bazaar respectively. Improvement in basic infrastructure such as, clean water supply, sanitation facilities, adequate drainage and ice facilities are recommended by the present study.
\end{abstract}

Keywords: livelihood status; fish retailers; fish markets

\section{Introduction}

Bangladesh is blessed with rich extensive inland and marine fisheries potential resources with a wide variety of indigenous and exotic fish fauna (Hasan et al., 2014). Bangladesh is the fifth leading country in the world for inland fisheries production (FAO, 2015). Fisheries sector contributes $2.46 \%$ of the country's export earning, $4.39 \%$ of its GDP, provides $60 \%$ of the national animal protein consumption and $22.76 \%$ to agricultural sector. It shows annual fish production 25,63,000 MT in 2007-2008 fiscal years which has increased up to 30,22,000 MT in 2010-11 and 32,62,000 MT in 2011-12 (DoF, 2013). In 2015 total employment in fisheries sector were 17.80 million people which $11 \%$ of the total population with a total fish production of 3684894 MT (DoF, 2015). A large amount of fishes ilish, chingri, boal, Tilapia, catla, rui, grass carp, mrigel, nilotica, koi, air, tengra, silver carp, bata, shol, taki, shing etc. are transported to Jashore town from different part of country. In Bangladesh, fish marketing is almost exclusively governed by the private sector where the livelihoods of a large number of people are associated with fish production and marketing systems. Bangladesh is called a riverine country due to the presence of a large number of rivers. Its plays an important role in the national economy of Bangladesh through employment generation, poverty alleviation, supply of animal protein and foreign exchange earnings (Rahman et al., 2015). According to Chambers and Conway (1992) livelihood comprise the 
capabilities, the assets (natural, physical, human, financial and social), the activities and the accesses to these that together determine the living gained by the individual household. Livelihood status of fish retailers mostly depend on fisheries resources. But the fishermen cannot catch fish properly due to economic, social and technical constraints. Thus, the socio-economic conditions of the fisher, farmer and retailers are not so good. They are not proficient to earn sufficient amount of money to meet basic needs. Fish retailer community is deemed to be one of the most vulnerable communities in terms of their livelihood opportunities in fisheries sector of Bangladesh. Most of the fish retailers are deprived of many amenities. All the times they have to struggle to survive, so, livelihood status of fish retailers community is not satisfactory at all. For proper development of fish retailers community, it is essential to understand the baseline information to initiate proper developmental steps and improve the livelihood of fish retailers. However, few studies on socio-economic conditions of fish retailers were carried out but all these efforts lack specific information of livelihood. Considering the importance of the matter, the present study was undertaken to study the socio-economic condition of fish retailers.

\section{Materials and Methods}

\subsection{Study area and periods}

Present investigation was conducted in three fish markets in Jashore sadar upazila namely, Boro Bazar $\left(23^{\circ} 10^{\prime} 02.5^{\prime \prime} \mathrm{N} 89^{\circ} 12^{\prime} 49.6^{\prime \prime E}\right)$, Palbari Bazar $\left(23^{\circ} 10^{\prime} 48.2^{\prime \prime N} 89^{\circ} 11^{\prime} 40.9^{\prime \prime E}\right)$ and Chuadanga Bus Stand Bazar $\left(23^{\circ} 10^{\prime} 11.5^{\prime \prime} \mathrm{N} 89^{\circ} 12^{\prime} 11.0^{\prime \prime} \mathrm{E}\right)$ to evaluate the socio-economic status of traders from March 2016 to August 2016.

\subsection{Study population}

There were taken total 45 fish retailers selected from the Jashore fish market. Both the professional and subsistence fish retailers living around the area of Jashore District.

\subsection{Data collection technique}

A planned questionnaire was developed containing both the closed and open ended query to collect data through face-to-face interview with the respondents. The questionnaire was pretested in areas far away from the sample areas and revised according to the feedback gained in the field level. The questionnaire was formed to obtain the relevant information considering socio-demographic condition, income of fishermen and family members, factors affecting the livelihood of the respondents and other relevant question of the fish retailers.

\subsection{Questionnaire interview with fish retailers}

The questionnaire was simple and focused on marketing as well as their socio-economic information. Each interview was consumed about half an hour.

\subsection{Statistical analysis}

The data were processed to undergo statistical analysis using SPSS 17 windows program. Microsoft Word, Microsoft Excel were used to represent the tabular and chart icon.

\section{Results}

\subsection{Age group distribution}

This study showed that, majority $42 \%$ of the fishermen was middle aged (21-40 years), other $18 \%$ was aged up to 20 years, $26 \%$ was aged $41-50$ years and $21 \%$ was old (50 years and above) aged group (Figure 1).

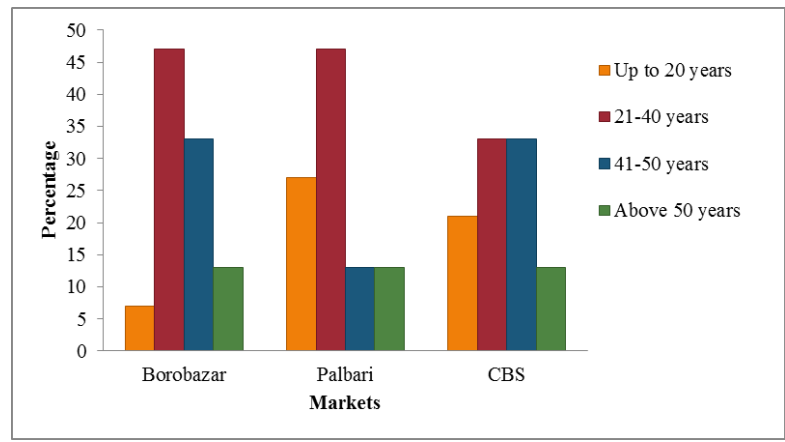

Figure 1. Age group distribution of fish retailers in the study area.

$*$ C.B.S = Chuadanga Bus Stand 


\subsection{Educational background}

Nearby, $42 \%$ had no education or illiterate, $31 \%$ traders had primary level of education, $24 \%$ had secondary level, 3\% had S. S. C. level of education and none of them H.S.C. and bachelor level of education (Figure 2).

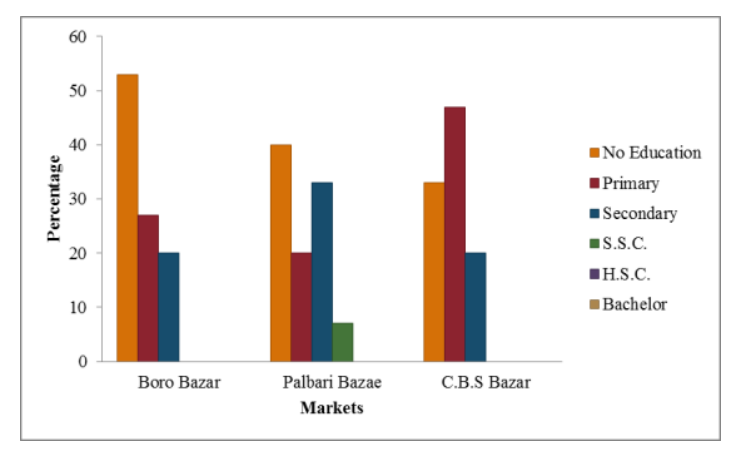

Figure 2. Educational background of fish retailers in the study area.

\subsection{Family type}

The study shows that $53 \%$ fish retailers had nuclear family and $47 \%$ had joint family (Figure 3 ).

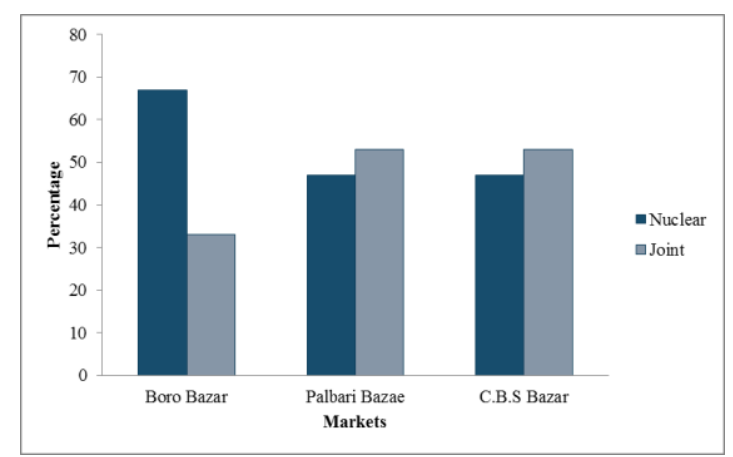

Figure 3. Family type of fish retailers in the study area.

\subsection{Religion}

In the study area, $80 \%$ of interviewed retailers were Muslims and the remainders $20 \%$ were Hindus, with no Christian or Buddhist (Figure 4).

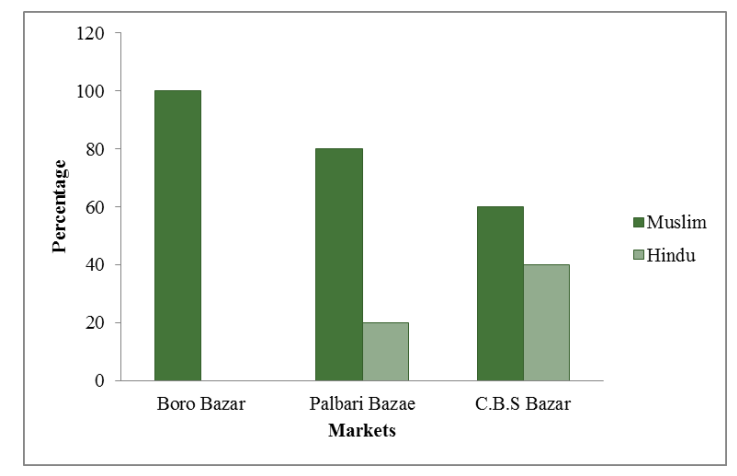

Figure 4. Religious status of fish retailers in the study area.

\subsection{Housing condition}

The study reveals that $69 \%$ of housing structures were Kacha (earthen floor and straw roof), while $27 \%$ were semi-pakka (Concrete floor and tin shed roof) and only $4 \%$ were pakka (Concrete floor and roof) (Figure 5). 


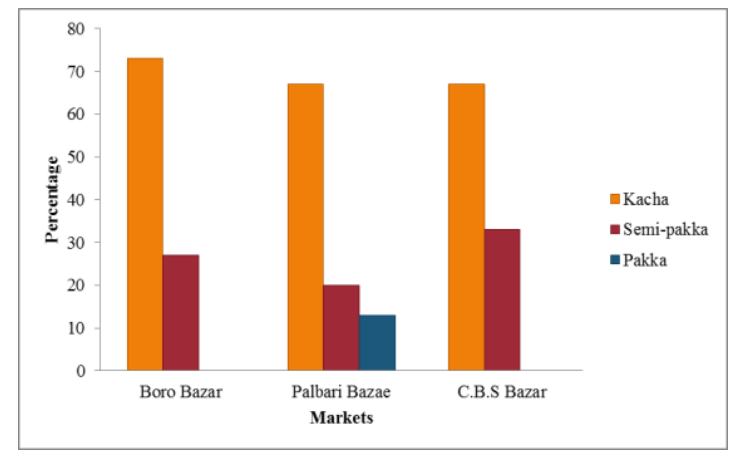

Figure 5. Housing condition of fish retailers in the study area.

\subsection{Drinking water facilities}

It was found that $100 \%$ of the retailer's household used tube wells for drinking water; among them $71 \%$ used own tube-wells for drinking water and the remaining $29 \%$ collected water from others tube-wells (Figure 6).

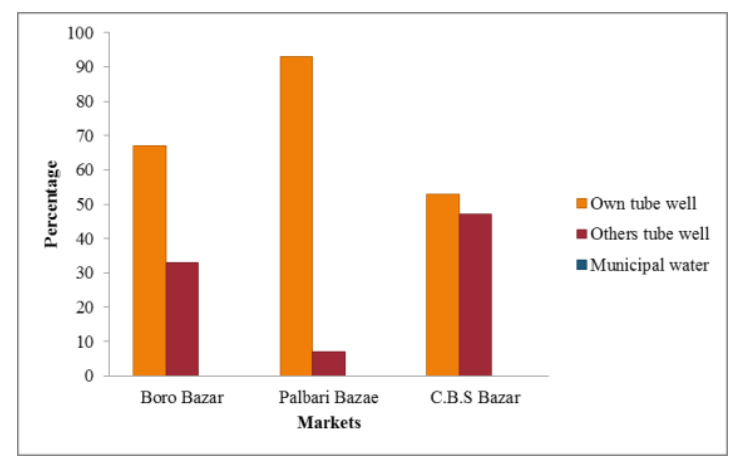

Figure 6. Drinking water facilities of fish retailers in the study area.

\subsection{Health facilities}

The study showed that $16 \%$ of retailers household were dependent on village doctor (unqualified practitioners), who did not have any understanding and knowledge of medical science, while $18 \%$ got health service from community hospital and $4 \%$ private clinic and $62 \%$ from upazila health complex (Figure 7 ).

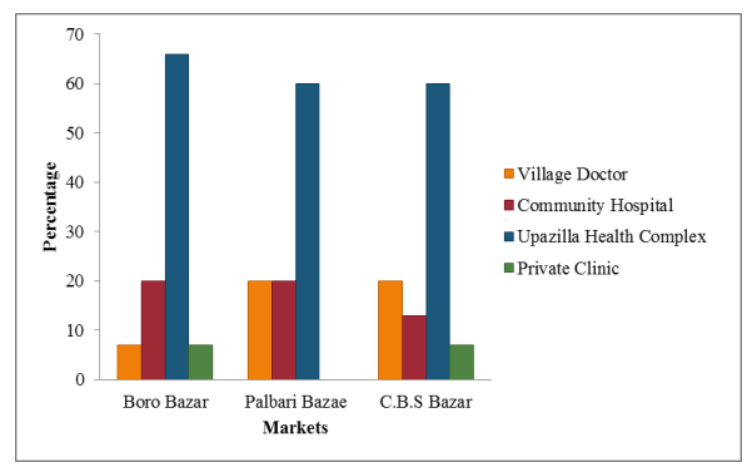

Figure 7. Health facilities of fish retailers in the study area.

\subsection{Income profit range}

Fish retailers are trying to improve their socio-economic conditions. During trading, fish retailers always tried to get maximum profit. But now a day, fish trading is a competitive job, as reported by the traders. According to the survey, The average net profit of fish retailers was found higher in Boro bazaar (350) followed by C.B.S. bazaar (TK.275) and Palbari bazaar (Tk. 325/day/retailers) (Table 1). 
Table 1. The average of net profit of fish retailers of three markets.

\begin{tabular}{llll}
\hline Name of markets & $\begin{array}{l}\text { Profit range (Peak season) } \\
\text { (Tk/day) }\end{array}$ & $\begin{array}{l}\text { Profit range (Off season) } \\
\text { (Tk/day) }\end{array}$ & $\begin{array}{l}\text { Average profit } \\
\text { (Tk/day) }\end{array}$ \\
\hline Boro Bazaar & 480 & 220 & 350 \\
Palbari Bazaar & 450 & 200 & 325 \\
C.B.S Bazaar & 400 & 150 & 275 \\
\hline
\end{tabular}

\subsection{Improvement of socio-economic condition}

Retailers generally operate a capital of around Tk. 300 to 600 per day. From the study, it was found that about $10 \%$ retailers used their own money for fish trading while the rest $90 \%$ received loans from moneylender or aratdars without paying any interest (Figure 8).

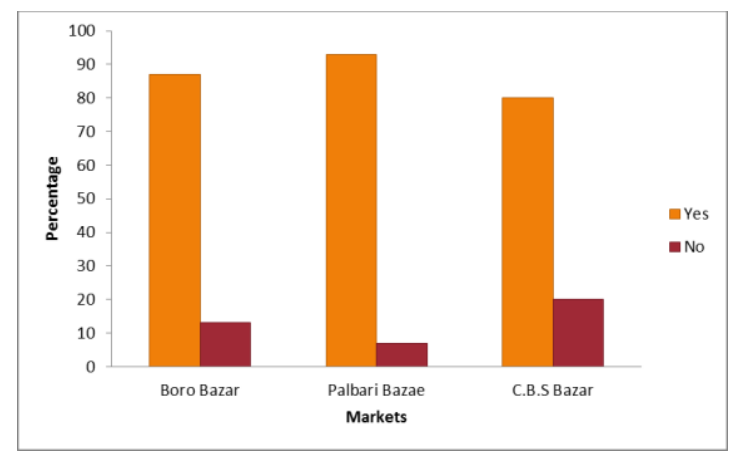

Figure 8. Improvement of socio-economic condition of fish retailers.

\subsection{Season and time of fish trading}

More or less the season of fish trading is year round. The traders of Boro bazaar, Chuadanga Bus stand bazaar are engaged in fish trading from $7 \mathrm{am}$ to $10 \mathrm{pm}$, Palbari bazaar from $9 \mathrm{am}$ to $4 \mathrm{pm}$. It was found that almost all traders of three markets spend around 8 to 12 hours in fish selling if sufficient fishes are available. But some traders can sell their fish earlier and engage themselves in other homestead works.

\subsection{Amount of fish sold}

It was found that a fish retailers of Boro bazaar and Palbari bazaar sold an average of $35 \mathrm{~kg}$ fish daily, compared with Chuadanga Bus stand bazaar $15 \mathrm{~kg}$ per day. There were about 100 retailers involved in Boro bazaar, about 20 retailers in Palbari bazaar and about 15 retailers in Chuadanga bus stand bazaar. The daily supply of fish in Boro bazaar can be estimated at $1.6 \mathrm{~m}$. tons $(25$ retailers $\times 65 \mathrm{~kg}$ ) while $0.3 \mathrm{~m}$. tons $(15$ retailers $\times 20 \mathrm{~kg})$ and $0.45 \mathrm{~m}$. tons ( 15 retailers $\times 30 \mathrm{~kg}$ ) in C.B.S and Palbari bazaar respectively.

\subsection{Fish availability of the market}

The fish species were available in Jashore fish market as, Rui (Labeo rohita), Catla (Gibelion catla) Tilapia (Oreochromis niloticus.) Ilish (Tenualosa Ilisha), Golda chingri (Macrobrachium rosenbergii), Bagda chingri (Penaeus monodon), Poa (Otolithoides pama), Tulardati (Sillaginopsis panijus), Bele (Glossogobius giuris),Ramsos (Thryssa hamiltonii), Koral (Lates calcarifer), Shing (Heteropneustes fossilis), Magur (Clarias sp.), Rita (Rita rita),Tengra (Mystus annulus), Air (Sperata aor), Deshi pangus (Pangasius pangasius), Thai pangus (Pangasius hypophthalmus), Koi (Anabas testudineus), Dhela (Osteobrama cotio), Mola (Amblypharyngodon mola), Sarputi (Puntius sarana), Raj puti (Barbonymus gonionotus),Shilong (Silonia silondia), Pabda (Ompok pabda), Boal (Wallago attu) etc.

\section{Discussion}

This present study presented that, bulk $42 \%$ of the fishermen was mid aged (21-40 years), other $18 \%$ was aged up to 20 years, $26 \%$ was aged $41-50$ years and $21 \%$ was old (50 years and above) aged group. According to Mondal et al. (2018) in 2005 Kattoli and Kumira has largest portion of the 20-30 age group, 55\% and 58\% respectively and according to survey, in 2018 it was found $30-40$ age group is dominant as $50 \%$ and $46 \%$ of total fisher population. Rahman (2003) noted that in Jashore the highest percentage of fish traders up to 30 age groups. Among 50 farmers, it was found that the highest proportions (36\%) of fish farmer were middle aged (31 
years-40 years) and above 50 years was the lowest (14\%) Adhikary et al. (2018). Kaiya et al, (1987) found that fish culture efficiency varied with the age and number of owners of pond in Tangail district. Vaumik et al. (2017) stated that, 30\% farmers remained 31-35 years old, 31\% were between 36-40 in Lalmonirhat district. Sharif et al. (2015) determined 85\% farmer has the age of 40 and above in Jessore district. Islam et al. (2015) founded in sundarban the maximum age level was 20-30 years old. Islam et al. (2014) revealed 44\% farmer had an age level 31-40 years as well as Asif and Habib (2017) research found the $38 \%$ people has an age group of 51-60 years which is similar with the present study.

Nearby, $42 \%$ had no education or illiterate, $31 \%$ traders had primary level of education, $24 \%$ had secondary level, $3 \%$ had S.S.C. level of education and none of them H.S.C. and bachelor level of education. Mondal et al. (2018) remarks primary education obtainer in two villages in Chittagong were $65 \%$ and $69 \%$ whereas Secondary education obtainer as $45 \%$ and $47 \%$ respectively. Mia (1996) found that most of the fish retailers had secondary level of education in his study in Jashore town. On the contrary, Dasgupta (2004) reported that majority of the fish traders in Fulpur upazila had primary level of education. Fish farmer had $44 \%$ education up to primary level, $24 \%$ fish farmer had secondary education, $18 \%$ had S.S.C passed and $14 \%$ had no education Adhikary et al. (2018). Zaman et al., (2006) found that 23.3\% farmers were illiterate whereas $14.4 \%, 8.9 \%$ and $6.7 \%$ were educated up to primary, secondary and higher secondary or above level respectively in Rajshahi district. Asif et al. (2015) 46\% of traders have institutional education; Asif and Habib (2017) stated 36\% had primary level, $42 \%$ had secondary level (up to X), $10 \%$ had S.S.C. level, $4 \%$ had H.S.C. level and $4 \%$ had bachelor level of education. Hossain et al. (2016) found most of the respondents (40\%) are illiterate. In Meherpur another study found $16 \%$ farmer had primary level, $36 \%$ had secondary level, $20 \%$ had S.S.C. level, $14 \%$ had H.S.C. level, and 6\% had bachelor level of education Islam et al. (2017). Hossain et al. (2015) mentioned only $18.33 \%$ are secondary educated in Dinajpur district. Rahman et al. (2017) mentioned that, 33\% of the contact farmers had up to secondary level of education (S.S.C) and only $7 \%$ of the contact farmers had masters' degree.

The present study showed that, 53\% fish retailers had nuclear family and $47 \%$ had joint family. Adhikary et al. (2018) found about $77 \%$ of fish farmer family was jointed and $23 \%$ percentage fish farmer family was nuclear. Joint family was predominant in the study area which also correspondents well with the findings of Ali et al. (2009) in Mymensingh district; Ali et al. (2016); Asif et al. (2015); Asif and Habib (2017); Hossain et al. (2015); Sharif et al. (2015); Vaumik et al. (2017) and Zaman et al. (2017) also found the similar family in their research. Moreover, it was found that Small family was $24 \%$, medium family was $54 \%$ and large family was 18\%. Farid et al. (2013) found that, 58\% fishermen were lived in joint families which are similar with the present study. Masud (2000) observed in his study that average family size of farmers related to fish culture in inundated water bodies was 6.36 (members) in Kishorgonj district. Gupta (2004) found that, there was no significant difference in average family size of retailers among the three markets.

In the study area, $80 \%$ of interviewed retailers were Muslims and the remainders $20 \%$ were Hindus, with no Christian or Buddhist. About 65\% Hindu communities and 35\% Muslim in two villages of Chittagong was denoted by Mondal et al. (2018). From the study it was found that Muslim fish traders (68.33\%) were predominant. Siddique (2001) mentioned that Muslim fish retailers were predominant in the market in Mymensingh. Khatun et al. (2013) observed in his study in Charbata in Noakhali district that 82\% of fish farmers were Muslims and $18 \%$ were Hindus. Sharif et al. (2015) observed that all of fish farmers (100\%) were Muslims that relates with my study. Asif et al. (2015); Hossain et al. (2015); Islam et al. (2014) and Islam et al (2015) also found the similar results.

The present study reveals that $69 \%$ of housing structures were Kacha (earthen floor and straw roof), while $27 \%$ were semi-pakka (Concrete floor and tin shed roof) and only $4 \%$ were pakka (Concrete floor and roof). About $69 \%$ households of the fish farmer were tinshed, $23 \%$ katcha and only $8 \%$ half building (Adhikary et al., 2018). Rahman (2003) reported that $70 \%$ of were katcha, while $21 \%$ were semi-pucca and only $9 \%$ were pucca in Gazipur district. Ahmed (2001) also found that $62 \%$ of katcha housing structure of prawn farmers in Mymensingh area. Asif and Habib (2017) stated around 88\% had concrete house in Jhikargachha upazila, Jessore which is not similar with the study. Sharif et al. (2015) found $54 \%$ farmers used semi pucca, $19 \%$ of fish farmers used to live pucca houses and rest of $27 \%$ farmers used to live earthen houses in Chaugachha, Jessore. Islam et al. (2014) revealed full katcha (17\%) houses were few, while the semipucca (40\%) and pucca (43\%) houses were more abundant.

It was found that $100 \%$ of the retailer's household used tube wells for drinking water; among them $71 \%$ used own tube-wells for drinking water and the remaining $29 \%$ collected water from others tube-wells. Hundred percentage of the studied fishermen used tube-wells' water for drinking purposes and among them 64\% fishermen had own tube-well and 36\% used neighbors tube-well (Adhikary et al., 2018; Mondal et al., 2018). 
Kabir et al. (2012) found that the highest (100\%) fishermen of the old Brahmaputra River used tube-well water for drinking purposes, among them $40 \%$ had their own tube-well, 50\% used shared tube-well and remaining $10 \%$ used neighbors tube-well. Same study conducted by Ali et al. (2016); Asif et al. (2015); Asif and Habib (2017); Hossain et al. (2015); Sharif et al. (2015); Rahman et al. (2014); Vaumik et al. (2017); Zaman et al. (2017); Shabuj et al. (2016); Siddika et al. (2016)and Razeim et al. (2017) also they have found the similar results.

The study showed that $16 \%$ of retailers household were dependent on village doctor (unqualified practitioners), who did not have any understanding and knowledge of medical science, while $18 \%$ got health service from community hospital and $4 \%$ private clinic and $62 \%$ from upazila health complex. Around $52 \%$ to $92 \%$ of fisher used to visit MBBS doctor which is found in two villages of Chittagong from the study of Mondal et al. (2018). Fourteen percentages took medical facility from upazila health complex and only $6 \%$ took medical facility from MBBS doctor (Adhikary et al., 2018). Ali et.al, (2008) found that $46 \%$ of the farmers received health service from village doctors, $18 \%$ from upazila health complex, $14 \%$ from district hospital and $20 \%$ from MBBS doctors in Rajshahi district. Asif et al. (2015); Asif and Habib (2017); Hossain et al. (2015); Sharif et al. (2015); Vaumik et al. (2017) and Islam et al. (2014) have had the similar results with present study.

According to the survey, the average net profit of fish retailers was found higher in Boro bazaar (350) followed by C.B.S. bazaar (TK.275) and Palbari bazaar (Tk. 325/day/retailers). From our survey it was found that the fish retailers make a significant amount of profit. Generally they make a profit of Tk. 150-600 per day. The fish retailers invest more capital than the wholesalers, and as such, they have greater control over the agent and retailers. The present findings are in agreement with the report of Rahman (2003) who observed similar scenario in Gazipur Sadar and Sripur upazila markets. Majority of farmers (48\%) had income around BDT 1000020,000 per month before fish farming and after fish farming $41 \%$ had above BDT 20,000-30,000 per month and income level of fish farmers increased and no one had income below BDT 10,000 per month. Average income of fish farmer was 15,000-25,000 per month (Adhikary et al., 2018; Leela et al., 2018). Okorie (2000) reported that average monthly income from cage culture was BDT 2250 (USD\$30). The highest percentage (34\%) fish farmers earned BDT 75,000 to 1,00,000 per year. It was higher than the national average BDT 28,430 (BBS, 2004). The present findings of annual income of fish farmers correspond well with the findings of Rahman et al. (2012) in Noakhali district and Rahaman et al. (2015) in Jashore district. Khan et al. (1986) stated that levels of family income are important economic factor affecting utilization of pond fish farming in Mymensingh district. Retailers generally operate a capital of around Tk. 300 to 600 per day. From the study, it was found that about $10 \%$ retailers used their own money for fish trading while the rest $90 \%$ received loans from moneylender or aratdars without paying any interest. Quddus (1991) reported similar seasonality for the prices of fish in Mymensingh fish markets. Rahman (2003) also mentioned that the price of fish varies with the season and highest prices are found in the summer and lowest in the winter in Gazipur. The traders of Boro bazaar, Chuadanga Bus stand bazaar are engaged in fish trading from 7am to $10 \mathrm{pm}$, Palbari bazaar from 9am to 4pm which is similar with the findings of Rahaman et al. (2015). It was found that almost all traders of three markets spend around 8 to 12 hours in fish selling if sufficient fishes are available. It was found that a fish retailers of Boro bazaar and Palbari bazaar sold an average of $35 \mathrm{~kg}$ fish daily, compared with Chuadanga Bus stand bazaar $15 \mathrm{~kg}$ per day. There were about 100 retailers involved in Boro bazaar, about 20 retailers in Palbari bazaar and about 15 retailers in Chuadanga bus stand bazaar. The daily supply of fish in Boro bazaar can be estimated at $1.6 \mathrm{~m}$. tons $(25$ retailers $\times 65 \mathrm{~kg})$ while $0.3 \mathrm{~m}$. tons $(15$ retailers $\times 20 \mathrm{~kg})$ and $0.45 \mathrm{~m}$. tons $(15$ retailers $\times 30 \mathrm{~kg})$ in C.B.S and Palbari bazaar respectively. Plethora fish species are aboundant in markets of Jashore sadar which is relevant with the study of Leela et al. (2018) and Samad et al. (2013).

\section{Conclusions}

Fish retailers, especially in developing countries, contribute to livelihood in a range of ways; as a source of income and through other social benefits, such as reduced vulnerability to poverty. Most of the fish retailers in the study area live in below the poverty level. Fish retailers' community is deemed to be one of the most vulnerable communities in terms of their livelihood opportunities in Bangladesh. Fish sell is main occupation of them which cannot be carried out throughout the year, they lack alternative job opportunities. The overall livelihood status of fish retailers' communities of this area is not good.

\section{Conflict of interest}

None to declare. 


\section{References}

Adhikary RK, S Kar, A Faruk, A Hossain, MNM Bhuiyan and AA Asif, 2018. Contribution of aquaculture on livelihood development of fish farmer at Noakhali, Bangladesh. Asian- Asian-Austra. J. Biosci. Biotech., 3:106-121.

Ahmed NU, 2001. Socio-economic aspects of freshwater prawn culture development in Mymensingh, Bangladesh. A report prepared for ICLARM.

Ali MH, MAK Azad, M Anisuzzaman, MMR Chowdhury, M Hoque and MI Sharful 2009. Livelihood status of the fish farmers in some selected areas of Tarakanda Upazila of Mymensingh district. Journal of Agrofor. Environ., 3: 85-89.

Ali MH, MD Hossain, ANGM Hasan and MA Bashar, 2008. Assessment of the livelihood status of the fish farmers in some selected areas of Bagmara upazilla under Rajshahi district. J. Bangladesh Agril. Univ., 6: 367-374.

Ali MM, AA Asif, MAI Shabuj, S Vaumik, MA Zafar and BMN Sharif, 2016. Status of polyculture Pangasius hypophthalmus with carps in Jhikargacha Upazila of Jessore District, Bangladesh. Int. J. Fish. Aqua. Stud., 4: 423-430.

Asif AA and MAB Habib, 2017. Socio-economic condition of fish farmers of Jhikargachha upazila in Jessore district, Bangladesh. Asian J. Med. Biol. Res., 3: 462-475.

Asif AA, MA Samad, MH Rahman, MA Farid, SM Yeasmin and BMS Rahman, 2015. Socio-economic condition of fish fry and fingerling traders in greater Jessore region, Bangladesh. Int. J. Fish. Aqua. Stud., 2: 290-293.

Chambers R and G Conway, 1992. Sustainable rural livelihoods: Practical concepts for the 21st century, Institute of Development Studies (IDS), Discussion Paper, University of Sussex, Brighton, UK. pp. 296.

Dasgupta S, 2004. Status of fish marketing in Fulpur upazilla, Mymensingh, MS Thesis, Department of Fisheries Management, Bangladesh Agricultural University, Mymensingh, pp. 62.

DoF, 2013. Department of Fisheries, Jatiyo Matsya Soptaho Sonkolon, Ministry of Fisheries and Livestock, the Government of Peoples Republic of Bangladesh, Dhaka. pp.13

DoF, 2015. Department of Fisheries, Jatiyo Matsya Soptaho Sonkolon, Ministry of Fisheries and Livestock, the Government of Peoples Republic of Bangladesh, Dhaka. pp.13

FAO, 2015. Food and Agriculture Organization of the United Nations. The State of world Fisheries and Aquaculture. Rome, Italy.

Farid ABBMS, S Mondal, KA Satu, RK Adhikary and D Saha, 2013. Management and socio-economic conditions of fishermen of the Baluhar Baor, Jhenaidah, Bangladesh. Journal of Fish, 1: 30-36.

Gupta SD, 2004. Status of Fish Marketing in Fulpur Upazila, Mymensingh. M.S. thesis. Department of Fisheries Management, Bangladesh Agricultural University, Mymensingh. pp.63.

Hossain MA, AA Asif, MA Zafar, MT Hossain, MS Alam and MA Islam, 2015. Marketing of fish and fishery products in Dinajpur and livelihoods of the fish retailers. Int. J. Fish. Aqua. Stud., 3: 86-92.

Hossain MZ, A Pal, MA Hasan, MS Parvej, N Nahar and AA Asif, 2016. Nutritional status and sociodemographic characteristics of the people of south-west coastal region in Bangladesh. Asian-Austra. J. Biosci. Biotech., 1: 323-332.

Islam FMK, AA Asif, M Ahmed, MS Islam, B Sarker, MA Zafar and M Rahman, 2017. Performances of resource poor households in aquaculture practices in sadar upazila, Meherpur, Bangladesh. Int. J. Fish. Aqua. Stud., 5: 281-288.

Islam MA, AA Asif, MA Samad, BMS Rahman, MH Rahman, A Nima and SM Yeasmin, 2014. Socioeconomic conditions of the fish farmers in Jessore, Bangladesh. Int. J. Bus. Soc. Sci. Res., 2: 153-160.

Islam MM, AA Asif, S Vaumik, MA Zafar, BMN Sharif, MH Rahman and S Shahriyar, 2015. Socio economic status of fry collectors at Sundarban region. Int. J. Fish. Aqua. Stud., 3: 89-94.

Kabir KMR, RK Adhikary, MB Hossain and MH Minar, 2012. Livelihood Status of Fishermen of the Old Brahmaputra River, Bangladesh. World Appl. Sci. J., 16: 869-873.

Kaiya MKU, MFA Mollah and MS Islam, 1987. Survey of pond resources of Mirzapur Upazila under Tangail district. Bangladesh J. Fish., 10: 37-43.

Khan MS, 1986. Socio-economic factors in the development of fisheries. Bangladesh J. Agril. Econ., 10: 43-47.

Khatun S, RK Adhikary, M Rahman, MNA Sikder and MB Hossain, 2013. Socio-economic status of pond fish farmers of Charbata, Noakhali, Bangladesh. Int. J. Life Sc. Bt. Pharm. Res., 2: 356-365.

Leela M, MFU Zaman, AA Asif and MA Hossain, 2018. Availability of fish species in fish markets and fish marketing in Noakhali district, Bangladesh. J. Ento. Zoo. Stud., 6: 1332-1344. 
Masud SM, 2000. An economic analysis of fish culture in inundated water bodies under the supervision of SAPAP in some selected areas of Kishorgonj district. M.S. Thesis, Department of Agricultural Economics, Bangladesh Agricultural University, Mymensingh, pp. 83.

Mia MGF, 1996. A study of production and marketing of culture fishes by the selected pond owners in Mymensingh district, MS Thesis, Department of Co-operation and Marketing, Bangladesh Agricultural University, Mymensingh. pp. 119.

Mondal MAI, MA Kader, AH Choudhury, MG Mustafa, MRU Nabi, MM Billah, AA Asif and AAM Siddiqui, 2018. Socio-economic uplifting analysis of ESBN fishery of the coastal villages, Kumira and Kattoli, Chittagong, Bangladesh. Int. J. Res. Grant., 6: 248-263.

Okorie PU, 2000. Socio-economic appraisal of cage culture Nogutake, Nigera. Department of Animal and Environmental Biology, ltrw State University. IMB, Owerri, Nigeria.

Quddus MA, 1991. Seasonal price movements of commercially important fishes in selected markets of Mymensingh district. Bangladesh J. Fish., 14: 63-68.

Rahaman MM, MA Zafar, BMN Sharif, P Paul, AA Asif, MM Islam and MI Hossain, 2015. Tilapia (Oreochromis mossambicus) marketing system in greater Jessore region, Bangladesh. Int. J. Fish. Aqua. Stud., 3: 95-103.

Rahman H, JA Mirza, A Hossain, AA Asif, E Haq, P Chwakravorty and M Rahman, 2017. Economics of fish production in paddy fields in Bangladesh. Asian J. Med. Biol. Res., 3: 379-390.

Rahman KMM, M Nahar, RK Adhikary, NS Khan, MM Rahman, M Asadujjaman and MA Rahman, 2014. Socio-economic condition and occupation migration of fisherman of the Jamuna river under Shirajgonj district in Bangladesh. Middle-East J. Sci. Res., 22: 633-638.

Rahman M, MF Tazim, SC Dey, AKMS Azamand and MR Islam, 2012. Alternative livelihood options of fishermen of Nijhum Dwip under Hatiya upazila of Noakhali district, Bangladesh Asian J. Rural Dev., 2: 2431.

Rahman MM, 2003. Status of fish marketing in Gazipur, Bangladesh. MS Thesis, Department of Fisheries Management, Bangladesh Agricultural University, Mymensingh, pp. 74.

Razeim MA, MG Farouque, MA Sarker, AA Asif and M Ahmed, 2017. Attitude of farmers towards Pangas farming for their livelihood improvement. Asian-Austra. J. Biosci. Biotechnol., 2: 106-119.

Samad MA, BMS Rahman, AA Asif and RK Audhikary, 2013. Availability and potentiality of small indigenous species of fish throughout the year in South-Western region of Bangladesh. African J. Basic App. Sci., 5: 167-173.

Shabuj MAI, AA Asif, O Faruq, MR Bari and MA Rahman, 2016. Brood stock management and induced breeding of Thai Pangus (Pangasius hypophthalmus) practiced in the hatcheries of Jessore region, Bangladesh. Int. J. Bus. Soc. Sci. Res., 4: 235-246.

Sharif BMN, AA Asif, S Vaumik, MA Zafar, MM Islam and MA Samad, 2015. Socio-economic condition of fish farmer and trader at the village of Pitamborpur in Chaugachha upazilla in Jessore, Bangladesh. Int. J. Fish. Aqua. Stud., 3: 212-217.

Siddika T, RK Adhikary, MHU Jaman, S Khondoker, N Tabassum and MFU Zaman, 2016. Socio economic conditions of the hatchery labors in Chanchra area of Jessore district in Bangladesh. Agric. For. Fish., 5: 3036.

Siddique MA, 2001. A study on socio-economic status of fishermen and fish marketing system in Mymensingh district, MS Thesis, Department of Fisheries Management, Bangladesh Agricultural University, Mymensingh, pp. 66.

Vaumik S, SK Sarker, MS Uddin, MT Alam, A Satter and AA Asif, 2017. Constraints and prospects of fish farming in Lalmonirhat District. Inter. J. Bus. Soc. Sci. Res., 5: 201-210.

Zaman T, MAS Jewel and AS Bhuiyan, 2006. Present status of pond fishery resources and livelihood of the fish farmers of MohanpurUpazila in Rajshahi District. Univ. J. Zool. Rajshahi Univ., 25: 31-35.

Zaman MFU, MA Samad, MA Islam, MHU Jaman, S Khondoker and AA Asif, 2017. Assessment of sustainability of Pangasius (Pangasius hypophthalmus) farming at Jhikargachha upazila in Jessore district, Bangladesh. Int. J. Faun. Biolo. Stud., 4: 109-119. 